\title{
Study on Three Platform Construction of Practice Base Outside School in Engineering Colleges based on Cooperation between School \& Enterprise
}

\author{
Ruijun Liu ${ }^{1 \text {, a }}$, Jianwei Zhang ${ }^{1}$, Bo Cui ${ }^{1}$, Yongming $\mathrm{Kang}^{1}$, Xing Wang ${ }^{1}$, Jinhe $\mathrm{Lv}^{1}$ \\ ${ }^{1}$ College of Automobile \& Civil Engineering, Beihua University, Jilin 132013, China. \\ a 254519852@qq.com
}

Keywords: Practice teaching, practice teaching, three platform construction.

\begin{abstract}
The practice teaching of practice teaching students not only to improve the practice ability plays a very important role in engineering college students, but also to improve the comprehensive professional qualities to adapt to society also great effect. This paper mainly to College of Automobile \& Civil Engineering of Beihua University professional electromechanical integration technology as subjects. The situation of engineering college education teaching practice perfecting three platform construction is putted forward to aimed at engineering colleges based on cooperation between school \& enterprise to develop practice teaching similar to provide the reference.
\end{abstract}

\section{Introduction}

Practice teaching is the main way of cultivating students' ability of applying technology in engineering colleges and universities, and it is also an important link in engineering education teaching in our country. The combination of work and study talents training mode in order to enhance the practical ability of students as a breakthrough point, the training of technical talents in engineering colleges plays an important role. The combination of learning and practice as the starting point to promote the theoretical knowledge and practical knowledge of the organic integration of engineering education is a distinctive feature of the reform of practical teaching. To explore the problems existing in the practical teaching with the combination of "work and study", to explore the measures to deepen the "combination of work and study" and to improve the quality of practical teaching in engineering education is of great significance to the improvement of the existing engineering education theories in China. Significance, for the training of engineering students' practical ability, innovation ability and entrepreneurial ability also has important theoretical guiding significance.

As an important link in the cultivation of engineering education, practical teaching plays an important role in cultivating students' practical ability, professional ability and entrepreneurial spirit. However, there are still a lot of problems in practice teaching in engineering colleges. Such as lack of practical teaching base, the enthusiasm of enterprises to participate in practice teaching is not high, practice teaching management is weak, practice teaching curriculum design is unreasonable and the lack of "double teacher" teachers. How to construct the practical and practical teaching system with the combination of "work and study" as the breakthrough point has important practical significance for cultivating the practical ability and employment ability of the engineering college students. This paper chooses Handan Polytechnic Institute of mechanical and electrical integration technology as the research object, through the professional practice of teaching the situation to do a case analysis to identify the professional in the practical teaching of the successful experience and shortcomings for our local similar Engineering colleges and universities can better carry out practical teaching to provide reference.

\section{Theoretical Basis of Practical Teaching in Engineering Education}

As early as the 1980s, a new theory of learning, the constructivist learning theory, was emerging in American education. It is generally believed that the idea of constructivism was first proposed by the 
famous Swiss psychologist Piaget. Piaget believes that children's understanding of the outside world is in its interaction with the surrounding environment in the process of gradually constructed, the child through its own initiative to build the main activities to make their own cognitive structure is developed. Later, the former Soviet Union education, psychologist Vygotsky's theory of constructivism was introduced to the United States, which greatly promoted the development of constructivist thought. Activities and social interaction on the psychological development of people play a more prominent role. He believes that people external action for its internalization process is the formation of their personal psychological process.

According to the constructivist view, knowledge is the representation of the objective reality, which is constructed on the basis of the original situation, and it is not a purely objective reflection of the real world. And the learning process of students is the process of students' active construction of new knowledge according to their original knowledge and experience under the specific teaching situation. Constructivism emphasizes the initiative of student learning, that students are the main body of learning, student knowledge is not passively by the teacher simply passed to him. Constructivism holds that the essence of learning is that the learners acquire knowledge by means of teachers' help, cooperation and communication with others, and active construction of meaning by their own in certain teaching situations.

In short, constructivist learning theory holds that students are the main body of learning, active constructors of knowledge meaning, and "context" plays an extremely important role in the construction of knowledge meaning. According to the constructivist learning theory, the practical teaching link is an indispensable link in engineering education. The real and rich actual situation is conducive to students' understanding of knowledge, and through the communication and cooperation between people in the real situation, students But also can enhance their professional ability, enhance their professional awareness, develop their professional spirit.

\section{The Connotation and Main Features of Practical Teaching in Engineering Education}

On the practical teaching of engineering education content, we can from the following aspects to understand:

1. From the engineering education goal, engineering education practice teaching is to develop the country needs high-quality, highly skilled technical talents.

The practice teaching of engineering education must be combined with the actual needs of a particular industry or technical positions, students can be competent for the job required production technology or skills. Practical teaching of engineering education to enhance students 'understanding of professional theory, to promote access to relevant vocational skills, practical experience in production practice, so as to enhance the students' comprehensive vocational ability for the purpose.

2. From the content of engineering education, engineering education is "application" as the main purpose to arrange the teaching content.

Engineering education in the basic theory of "necessary, enough to" principle, professional courses emphasize the relevance and practicality. As a result, the practice teaching of engineering education mainly includes two aspects: one is the classroom teaching in order to consolidate the professional theoretical knowledge and targeted simulation experiments; the second is the students learn the professional knowledge, skills used in practice, And in the course of practice to promote their vocational skills more proficient in the school training and off-campus practice.

From the relationship between practical teaching and theoretical teaching, the practical teaching of engineering education must not be completely separated from the theoretical teaching alone. In fact, practical teaching and theoretical teaching are interrelated and mutually reinforcing. On the one hand, theoretical teaching is the basis of practical teaching; on the other hand, practical teaching is to further deepen and consolidate the theoretical teaching.

The comprehensive practice teaching is mainly embodied in the goal of practical teaching. First of all, the practical teaching of engineering emphasizes the cultivation of students 'practical skills, and also fosters the cultivation of students' professional quality. Through practice teaching, not only to 
develop students with a certain degree of professional knowledge and professional skills, but also to develop students with people and the ability to collaborate and the flexibility to adapt to the ability of professional positions; to teach students how to do, how to do things; to train students to become Sound personality, with good professional ethics and quality of high-quality, high-skilled compound talents.

The practical teaching of engineering education, from the time arrangement, it refers not only to students before the graduation period of practice, in fact, engineering education practice teaching refers to the whole period from freshmen to graduate school during the entire teaching professional process. This is the penetration of practical teaching. Engineering education, classroom teaching, school training, off-campus practice are all filled with the content of practical teaching. Classroom teaching content is the theoretical basis for the formation of practical skills of students, school training is to further consolidate the theoretical knowledge of the classroom, off-campus practice is for the future employment of students to do further preparation. These three links are closely linked, inseparable, together constitute the complete content of practical teaching. Students practice skills is not a jump on the need to continue through repeated training, strengthening, which is the embodiment of teaching through practice.

The practical teaching methods in engineering colleges are mainly classroom teaching, in-school training and off-campus practice. Classroom teaching often use multimedia case teaching method to highlight the problem situation, the school training is often used "simulation-like analog site" to approach the future employment environment of students, and off-campus practice is in the actual workplace, students through The actual workplace can fully experience the real occupational environment. These all reflect the situation of practical teaching.

\section{Deepening the Combination of Work and Study to Improve the Quality of Practical Teaching in Higher Vocational Education}

According to the questionnaire, students in practice outside the school is often a lack of practical teachers and business instructors to help and factory. To this end, the higher vocational colleges in the students' practice outside the first practice of teachers to strengthen the management of the work, to avoid the work of instructors in the form of practical work in order to enable students to better guide students to study and practice; To strengthen the industry and technology backbone of the practice of students outside the guidance of the work, so that students can practice in the field to achieve greater gains; Furthermore, the vocational schools should further strengthen the assessment of students' practice and evaluation. In the assessment and evaluation of students' practice outside the school, the school can establish student practice files, timely feedback on student internship.

Strengthening the construction of production-based training base, practice-based practice base, and constantly improve the practice of integrated theory and practice of teaching is fully integrated with the practice of vocational education curriculum reform is an important content. On the one hand, the vocational colleges should further expand the campus training base, update and add internship training facilities; According to the survey of students, a considerable number of students think that simulation-like training will help them to adapt to the real work environment. The use of modern teaching methods, such as multimedia teaching and network teaching, has also greatly improved the effectiveness of classroom practice teaching. The vocational colleges should also be appropriate to increase students internship opportunities outside the post, so that students can feel the real business environment for students to prepare for future employment. The institutions through the sharing of resources, complementary ways to form a combination of school and outside, the real environment and simulation of a combination of practice and training base.

\section{Conclusion}

Practice teaching not only plays an important role in improving the practical ability of engineering students, but also plays an important role in improving engineering students to adapt to the social 
comprehensive professional accomplishment. Doing well in practice teaching is the key to improving the quality of personnel training in engineering colleges and universities, but also an important measure to improve the employment rate of engineering graduates.

The results of this paper are mainly based on the case analysis of the practical teaching of Vehicle Engineering in Beihua University and the status quo of practical teaching in engineering colleges in China, and put forward four suggestions to improve the practice teaching of engineering in our country: The second is to optimize the curriculum of engineering colleges and universities, and gradually improve the curriculum system of "studying in school"; thirdly, to build a "double-qualified" teaching staff, and constantly improve the professional teaching team To improve the professional skills of teachers; Fourth, we must deepen the "combination of work and study" to improve the quality of engineering education practice teaching.

This paper mainly focuses on the lack of detailed research on the development of practical teaching from many aspects, such as the protection of practical teaching, how to improve their practical skills, and so on, so that they can not from the complete practice Teaching system. In addition, in the survey, due to the smaller sample selection, thereby reducing the effectiveness of the paper. In view of the shortcomings of the paper, the author hopes to make further improvements in the future research, and hope that more engineering educators to join the practice of teaching research.

Acknowledgments: Education teaching and research topics of Beihua University[the Three platform construction of Practice Base Outside School in engineering colleges based on cooperation between school and enterprise-2016]

\section{References}

[1] He Min.Study on the Practical Teaching Mode of "Workplace" in Higher Vocational Art Design Education.Nanjing Art Institute, 2008.

[2] Yao Jinye, Practice and Exploration of the Mode of Combining Talent Cultivation with Work and Study. Huazhong University of Science and Technology, 2008.

[3] Liu Yunhua.Study on the Transformation of Ideological and Political Education in Higher Vocational Education under the Mode of "Combination of Work and Study". Hebei Normal University, 2009.

[4] A Study on the Process Management of Practical Teaching in Higher Vocational Colleges Taking Hunan Landscape Biology Vocational College of Garden Technology as an Example. Hunan Agricultural University, 2009.

[5] Li Xiaolu.Study on Employment Problems and Countermeasures of Higher Vocational College Graduates. Hebei Normal University, 2007.

[6] The Analysis and Countermeasures of the Combination of Work and Study in Guangxi Higher Vocational Education - Based on the Theory of Practice of Three Higher Vocational Colleges.

[7] Research on Practical Teaching of Tourism Major in Lianyungang Higher Vocational College.Nanjing Normal University, 2008.

[8] Zheng Xueping.Study on the Problems and Countermeasures of Training Mode of Combination of Work and Study in Vocational Education. Hebei Normal University, 2008. 